\title{
Kumulasi Gugatan Perbuatan Melawan Hukum dan Gugatan Wanprestasi Dalam Kajian Hukum Acara Perdata di Indonesia
}

\author{
1. Rai Mantili
}

\author{
2. Sutanto \\ 1. Doctoral Student, Faculty of Law, Gadjah Mada University \\ rai_fdl@yahoo.com, sutanto_fh@mail.ugm.ac.id
}

Submitted: 2019-02-11; Reviewed: 2019-03-26; Accepted: 2019-04-28

\begin{abstract}
This article describes the integration of lawsuits in breach of law or breach of contract which often found in court examination practice. First issue will analyze whether the integration of lawsuits can be conducted between breach of law and breach of contract claims pursuant to Indonesian Civil Procedures. The second issue will analyze the legal consideration of judges who reject the integration of lawsuits between breach of law and breach of contract claims pursuant to Indonesian Civil Procedures

There are some of opinions of judges or expert against the integration of lawsuits between breach of law and breach of contract claims. A jurisprudence states that the integration of lawsuit between breach of law and breach of contract claim in lawsuit is violating the code of conduct since both shall be examined respectively. $H I R, R B G$ and $R V$ does not strictly stipulate and prohibit the integration of lawsuit, however, pursuant to Jurisprudence of The Supreme Court of the Republic of Indonesia No. 1875K/Pdt/1984 dated April 24, 1986, "the integration of lawsuits between the breach of law and breach of contract claims cannot be conducted since it is violating the civil procedures and accordingly it shall be examined respectively. In accordance with such jurisprudence, the Judex Jurist is authorized to declare that the integration of lawsuits between the breach of law and breach of contract claims is unacceptable lawsuit (NO/niet oontvankelijk verklaard).
\end{abstract}

Keywords: Breach of law; breach of contract; civil procedure; integration of lawsuits. 


\section{PENDAHULUAN}

Tugas dan kewenangan lembaga peradilan di bidang perdata adalah menerima, memeriksa, mengadili serta menyelesaikan sengketa diantara para pihak yang berperkara. Sifat dari hukum acara perdata yang merupakan hukum formal yaitu hukum mengenai proses dalam penyelesaian sengketa melalui pengadilan, dan mengikat bagi semua pihak serta tidak dapat disimpangi, sehingga hukum hukum acara perdata memiliki sifat publik ${ }^{1}$. Pengadilan tidak hanya memeriksa perkara yang mengandung sengketa atau yang disebut gugatan contentiosa saja, tapi juga berwenang untuk memeriksa perkara voluntair yang bersifat sepihak (ex-parte) yang semata-mata hanya untuk kepentingan pemohon saja.

Hasil penelitian lapangan menunjukkan bahwa gugatan perdata yang ada di pengadilan didominasi oleh gugatan perbuatan melawan hukum, disamping tentunya gugatan wanprestasi kontrak ${ }^{2}$. Untuk mengajukan gugatan perbuatan melawan hukum harus dipastikan terpenuhinya sebagaimana ketentuan dalam Pasal 1365 KUHPerdata, sedangkan untuk mengajukan gugatan wanprestasi harus memenuhi ketentuan dalam Pasal 1243 KUHPerdata.

Ruang lingkup kerugian dalam perbuatan melawan hukum memiliki dimensi yang berbeda dengan wanprestasi. Seseorang dapat dikatakan wanprestasi apabila ia melanggar suatu perjanjian yang telah disepakati dengan pihak lain sedangkan seseorang dapat dikatakan melakukan melawan hukum apabila perbuatannya bertentangan dengan hak orang lain, atau bertentangan dengan kewajiban hukumnya sendiri, atau bertentangan dengan kesusilaan. Persamaan dari gugatan wanprestasi dan melawan hukum adalah dapat diajukan tuntutan ganti rugi

Pihak yang mengajukan tuntutan ke pengadilan sering mencampuradukkan antara gugatan wanprestasi dan gugatan melawan hukum. Sering terjadi pihak yang mengajukan gugatan melawan hukum namun dari dalil-dalil yang dikemukakan terlihat bahwa gugatannya adalah wanprestasi. Kesalahan dalam dalil gugatan dapat menjadi celah yang akan dimanfaatkan tergugat dalam tangkisannya. Beberapa ahli memberikan komentar bahwa melawan hukum dengan wanprestasi memiliki persamaan dengan batasan-batasan tertentu. Asser Ruten, sarjana hukum Belanda, berpendapat bahwa tidak ada perbedaan yang hakiki antara melawan hukum dan wanprestasi. Menurutnya, wanprestasi bukan hanya pelanggaran atas hak orang lain, melainkan juga merupakan gangguan terhadap hak kebendaan. Yahya Harahap pun berpendapat bahwa dengan tindakan debitur dalam melaksanakan kewajibannya yang tidak tepat waktu atau tak layak, jelas itu merupakan pelanggaran hak kreditur. Setiap pelanggaran hak orang lain berarti merupakan melawan hukum. Dikatakan pula, wanprestasi adalah species, sedangkan genusnya adalah melawan hukum. ${ }^{3}$

\footnotetext{
${ }^{1}$ Efa Laela Fakhriah, Bukti Elektronik Dalam Sistem Pembuktian Perdata edisi ke 2, Jakarta: Alumni, 2011, hlm. 195.

${ }^{2}$ Munir Fuady, Perbuatan Melawan Hukum, Bandung: Citra Aditya Bakti, 2017, hlm.1

${ }^{3} \mathrm{http} / / /$ pkbh.uad.acc.id, diakses pada tanggal 10 Oktober 2018, pukul 10.34 WIB.
} 
Apabila dicermati kembali, ada suatu perbedaan hakiki antara sifat perbuatan melawan hukum dan wanprestasi. Pitlo menegaskan bahwa baik dilihat dari sejarahnya maupun dari sistematik undang-undang, wanprestasi tidak dapat digolongkan pada pengertian melawan hukum. M.A. Moegni Djojodirdjo dalam bukunya yang berjudul "Perbuatan melawan hukum", berpendapat bahwa amat penting untuk mempertimbangkan apakah seseorang akan mengajukan tuntutan ganti rugi karena wanprestasi atau karena melawan hukum. Menurut Moegni, akan ada perbedaan dalam pembebanan pembuktian, perhitungan kerugian, dan bentuk ganti ruginya antara tuntutan wanprestasi dan melawan hukum. Pada gugatan melawan hukum, penggugat harus membuktikan semua unsur-unsur melawan hukum selain harus mampu membuktikan adanya kesalahan yang diperbuat debitur. Dalam gugatan wanprestasi, penggugat cukup menunjukkan adanya wanprestasi atau adanya perjanjian yang dilanggar. Dalam suatu gugatan melawan hukum, penggugat dapat menuntut pengembalian pada keadaan semula (restitutio in integrum). Namun, tuntutan tersebut tidak dapat diajukan apabila gugatan yang diajukan dasarnya adalah wanprestasi. ${ }^{4}$

Dalam posita gugatan perbuatan melawan hukum yang diuraikan adalah perbuatan-perbuatan yang dianggap bertentangan dengan hukum dan undangundang serta serta sering dikaitkan dengan permintaan ganti rugi immateriil. Dalam membuat surat gugatan harus dipahami mengenai para pihak yang digugat, dan kualitas perbuatan yang dibuat para pihak. Tuntutan pokok dalam perbuatan melawan hukum harus didahului dengan peristiwa hukum, yaitu apa yang telah dilanggar Tergugat, tempat dimana peristiwa itu dilakukan sehingga dapat disimpulkan bahwa perbuatan tersebut benar adanya mengenai gugatan perbuatan melawan hukum.

Hal lain yang diatur antara permintaan ganti rugi akibat wanprestasi dan perbuatan melawan hukum adalah dalam tuntutan ganti rugi akibat wanprestasi jumlahnya dapat diperkirakan karena ada dalam perjanjian, sedangkan untuk tuntutan ganti rugi aibat perbuatan melawan hukum tidak dapat diperkirakan. Namun, pada praktiknya untuk pemenuhan tuntutan kerugian diserahkan kepada Hakim dengan prinsip ex aquo et bono ${ }^{5}$. Ex aequo et bono adalah frase yang merupakan bagian petitum dalam suatu gugatan atau permohonan. Biasanya digabung dengan kalimat "kalau majelis hakim berpendapat lain, mohon putusan yang seadil-adilnya (ex aequo et bono)...".

Dalam sistem Kitab Undang-Undang Hukum Perdata ada berbagai macam gugatan yang tidak boleh dicampur adukkan yang memiliki arti bahwa seorang penggugat tidak cukup meminta peradilan begitu saja, melainkan ia harus mengutarakan (stellen) dan apabila perlu, membuktikan suatu pelanggaran dari pasal tertentu dari Kitab Undang-Undang Hukum Perdata atau undang-undang lain, dan juga ia harus menentukan semula apa yang ia minta, yaitu misalnya

\footnotetext{
${ }^{4}$ Ibid

${ }^{5}$ http://www.hukumonline.com/klinik/detail/lt4da27259c45b9/di-mana-pengaturan-kerugian konsekuensial-dalam-hukum-indonesia, diakses pada tanggal 7 Oktober 2018, pukul 16.45 WIB.
} 
penyerahan suatu barang tertentu, atau pengosongan suatu bangunan atau pembayaran ganti kerugian berwujud uang atau berwujud lain, atau suatu perbuatan tertentu, atau larangan melakukan suatu perbuatan tertentu yang tergugat juga belum pernah melakukan tetapi akan melakukan, kalau tidak dilarang. ${ }^{6}$

Hukum positif di Indonesia tidak mengatur tentang kumulasi gugatan perdata. Meskipun tidak diatur dalam hukum positif namun peradilan sudah lama menerapkan kumulasi gugatan. Soepomo menunjukkan salah satu putusan Raad Justisie Jakarta pada tanggal 20 Juni 1939 yang memperbolehkan kumulasi gugatan, asal antara gugatan-gugatan itu terdapat hubungan erat (innerlijk samnehang). ${ }^{7}$ Pendapat yang sama ditegaskan dalam Putusan MA No. 575 K/Pdt/1983 yang menjelaskan antara lain:

1. Meskipun Pasal 393 ayat (1) Het Herziene Indonesisch Reglement (HIR) mengatakan hukum acara yang diperhatikan hanya HIR, namun untuk mewujudkan tercapai process doelmatigheid, dimungkinkan menerapkan lembaga dan ketentuan acara di luar yang diatur dalam HIR, asal dalam penerapan itu berpedoman kepada ukuran:

a. Benar-benar untuk memudahkan atau menyederhanakan proses pemeriksaan

b. Menghindari terjadinya putusan yang saling bertentangan.

2. Berdasarkan alasan itu, boleh dilakukan kumulasi (samenvoeging) atau kumulasi objektif maupun subjektif, asal terdapat innerlijke samenhangen atau koneksitas erat diantaranya. ${ }^{8}$

Suatu tuntutan hak harus mempunyai kepentingan hukum yang cukup dan hal tersebut merupakan syarat utama untuk dapat diterimanya tuntutan hak itu oleh pengadilan (point d'interet, point d'action) namun tidak berarti bahwa setiap tuntutan hak yang ada kepentingan hukumnya akan dikabulkan oleh pengadilan. Pengadilan akan mengabulkan tuntutan hak bila setelah dilakukan proses pembuktian, pengadilan berpendapat bahwa tuntutan hak yang diajukan tersebut terbukti dan didasarkan bahwa tuntutan hak yang diajukan tersebut terbukti dan didasarkan adanya suatu hak. ${ }^{9}$

Salah satu contoh putusan pengadilan yang tidak mengabulkan suatu gugatan karena tidak sesuai dengan dalil gugatanya adalah Putusan Pengadilan Negeri Kediri Nomor : 70 /Pdt.G/2011/PN.Kdr yang memutus perkara antara Drs. Maruto Asmoro, (Penggugat) dan Rr. Rully Kushartuti (Penggugat II) melawan Rukiyati (Tergugat I), Budi Setyono (Tergugat II), Adira Financa (Tergugat III). Putusan pengadilan ini memutus Dalam konvensi Menyatakan gugatan Para Penggugat

\footnotetext{
${ }^{6}$ Wirjono Prodjodikoro, Perbuatan Melanggar Hukum, Cetakan I, Bandung: Mandar Maju, 2000, hlm. 101 .

7 Soepomo dalam Yahya Harahap, Hukum Acara Perdata Tentang Gugatan, Persidangan, Penyitaan, Pembuktian dan Putusan Pengadilan, Jakarta: Sinar Grafika, Jakarta, 2006.

${ }^{8}$ Ibid

9 Sunarto, Peran Aktif Hakim Dalam Perkara Perdata, Jakarta: Kencana Prenada Media Group, 2014, hlm. 82.
} 
Konvensi tidak dapat diterima (Niet Ontvankelijk Verklaard) dan dalam Rekovensi menyatakan gugatan Penggugat Rekonpensi tidak dapat diterima (Niet Ontvankelijk Verklaard).

Awal perkara ini terjadi ketika Tergugat I dan Tergugat II datang pada Penggugat I dan Penggugat II untuk meminjam modal kerja. Penggugat I dan Penggugat II menyatakan tidak memiliki dana yang diperlukan oleh Tergugat I dan Tergugat II. Oleh karena Penggugat I tidak dapat memberikan pinjaman, maka Tergugat I dan Tergugat II meminjam BPKB No. 1954593J Kijang Innova No. Pol. AG 1173 AC atas nama Penggugat I. Kemudian Penggugat I baru mengetahui bahwa mobil miliknya dijaminkan oleh Tergugat I dan Tergugat II di tempat Tergugat III sebesar Rp. 90.000.000,- (sembilan puluh juta rupiah). Namun berdasarkan jawaban dari Tergugat I dan II dinyatakan bahwa Penggugat I dan Penggugat II lah yang sebenarnya memiliki utang kepada Tergugat I dan Tergugat II yang pertama sebesar Rp. 30. 000. 000 ( tiga puluh juta rupiah ) dan yang kedua Rp. 10.000.000 ( sepuluh juta rupiah ) dan para Penggugat sendiri yang menawari akan menambah tambahan pinjaman kepada Tergugat I dan Tergugat II masing masing Rp.20.000.000 (dua puluh juta rupiah) dan yang ke dua sebesar Rp 50.000.000, (lima puluh juta rupiah) karena tawaran itu akan digunakan sebagai tambah modal kerja yang akhirnya diterima oleh Tergugat I dan Tergugat II semuanya berjumlah Rp. 110.000.000 ( seratus sepuluh juta rupiah ) dan BPKB No .1954593J Kijang Innova No Pol AG 1173 AC atas nama Penggugat I (dan atas persetujuan dan pengetahuan Penggugat I dan II, BPKB yang tersebut di atas di jaminkan sebagai barang bukti jaminan pijaman ke Tergugat III sebesar Rp 90.000.000 ( sembilan puluh juta rupiah ).

Pertimbangan hakim menyatakan bahwa gugatan tidak dapat diterima (Niet Ontvankelijk Verklaard) karena formulasi gugatan terutama pada kumulasi subjektif yang tidak jelas dengan mencampuradukkan PMH dengan Wanprestasi pada Tergugat I, II dan III secara sekaligus menjadikan gugatan aquo membingungkan serta menimbulkan konsekwensi pembuktian yang tidak sederhana atau rumit, sehingga dengan demikian gugatan mengandung cacat secara hukum. Pertimbangan lainnya adalah gugatan Para Penggugat Konpensi tersebut, Majelis Hakim berpendapat bahwa sesuai dengan putusan Mahkamah Agung sebagaimana terurai diatas dalam penggabungan gugatan disyaratkan keduanya terdapat hubungan erat (innerlijke samenhangen), dalam perkara ini menurut hemat Majelis Hakim antara gugatan wanprestasi yang ditujukan kepada Tergugat I dan Tergugat II dengan gugatan perbuatan melawan hukum yang ditujukan kepada Tergugat III meskipun mempunyai hubungan kausal, namun penggabungan yang demikian tidak tepat justru mengaburkan gugatan Para Penggugat.

Putusan hakim yang menolak gugatan perbuatan melawan hukum dan wanprestasi dapat menimbulkan perdebatan hukum sendiri. Yoni A Setyono Pengajar Hukum Acara Perdata Universitas Indonesia berpendapat bahwa kumulasi gugatan perbuatan melawan hukum dan wanprestasi secara hukum tidak 
diperbolehkan. Namun, seperti diketahui bahwa dalam peradilan perdata hakim bersifat pasif sehingga para pihak yang bersengketa harus lebih aktif dalam mengungkapkan argumentasinya ${ }^{10}$.

Pada praktik dilapangan, hakim pengadilan tidak semua menolak perkara yang berisi kumulasi gugatan wanprestasi dan perbuatan melawan hukum dalam satu gugatan. Hal ini dapat dilihat dari yurisprudensi Mahkamah Agung dalam Putusan Mahkamah Agung No. 2686/Pdt/1985 tanggal 29 Januari 1987. Yahya Harahap menyatakan bahwa walaupun dalam putusan Mahkamah Agung tersebut dalil gugatan yang dikemukakan dalam gugatan adalah perbuatan melawan hukum dan persitiwa hukum yang sebenarnya adalah wanprestasi, gugatan tidak obscuur libel karena hakim dapat mempertimbangkan bahwa dalil gugatan itu dianggap wanprestasi ${ }^{11}$. Pendapat Yahya harahap serupa dengan putusan Mahkamah Agung No. 886/Pdt/K/2007 tanggal 24 Oktober 2007 yang menyatakan dalam pertimbangan hukumnya "bahwa sungguhpun dalam gugatan terdapat posita wanprestasi dan perbuatan melawan hukum, akan tetapi dengan tegas diuraikan secara terpisah, maka gugatan demikian yang berupa kumulasi obyektif dan dapat dibenarkan".

Banyak perbedaan pendapat baik dari hakim pengadilan maupun dari para ahli mengenai kumulasi gugatan wanprestasi dan perbuatan melawan hukum. Yurisprudensi yang menyatakan kumulasi gugatan perbuatan melawan hukum dengan wanprestasi dalam satu gugatan adalah melanggar tata tertib beracara karena keduanya harus diselesaikan tersendiri. Namun ada juga pendapat dalam yurisprudensi lain yang membolehkan dilakukan kumulasi gugatan perbuatan melawan hukum dan wanprestasi dalam satu gugatan dengan alasan apabila dalam gugatan terdapat posita wanprestasi dan perbuatan melawan hukum, akan tetapi dengan tegas diuraikan secara terpisah maka gugatan demikian yang berupa kumulasi objektif dapat diterima. Oleh karena itu, sangat menarik untuk menganalisa bagaimana sebenarnya pengaturan kumulasi gugatan perbuatan melawan hukum dan wanprestasi ditinjau dari hukum acara perdata di Indonesia.

Berdasarkan pemaparan yang telah diuraikan di atas, maka dapat ditarik permasalahan hukum adalah yang Pertama apakah dalam suatu gugatan dapat dibuat kumulasi gugatan antara wanprestasi dan perbuatan melawan hukum ditinjau dalam hukum acara perdata di Indonesia dan yang kedua bagaimana pertimbangan hukum dari hakim yang menolak kumulasi gugatan wanprestasi dan perbuatan melawan hukum, ditinjau dari hukum acara perdata di Indonesia.

\section{PEMBAHASAN}

Kumulasi Gugatan Wanprestasi Dan Perbuatan Melawan Hukum Ditinjau menurut hukum acara perdata di Indonesia

\footnotetext{
${ }^{10} \mathrm{https} / / / \mathrm{m}$.hukumonline.com, diakses pada tanggal 10 Oktober 2018, pukul 7.30 WIB.

${ }^{11}$ Yahya Harahap, Op.Cit, hlm 77
} 
Surat gugatan adalah suatu permohonan yang disampaikan kepada Ketua Pengadilan Negeri yang berwenang, mengenai suatu tuntutan terhadap pihak lainnya dan harus diperiksa menurut tata cara tertentu oleh pengadilan, serta kemudian diambil putusan terhadap gugatan tersebut ${ }^{12}$. Sudikno Mertokusumo menyebut surat gugatan dengan tuntutan hak sebagai tindakan yang bertujuan untuk memperoleh perlindungan yang diberikan oleh pengadilan untuk mencegah "eigenrichting" 13 .

Bentuk dari surat gugatan dapat dibuat secara lisan maupun secara tertulis. Surat gugatan secara lisan sebagaimana diatur dalam Pasal 120 HIR, Pasal 144 Rbg). Namun, perkembangan saat ini gugatan lisan sudah tidak lazim lagi, bahkan menurut Yurisprudensi MA tanggal 4-12-1975 Nomor 369 K/Sip/1973 orang yang menerima kuasa tidak diperbolehkan mengajukan gugatan secara lisan.

Pada prinsipnya setiap gugatan harus berdiri sendiri, masing-masing gugatan diajukan dalam surat gugatan yang terpisah secara tersendiri, dan diperiksa serta diputus dalam proses pemeriksaan dan putusan yang terpisah dan berdiri sendiri. Akan tetapi dalam hal dan batas-batas tertentu dibolehkan melakukan penggabungan gugatan dalam satu surat gugatan apabila antara satu gugatan dengan gugatan yang lain terdapat hubungan erat atau koneksitas ${ }^{14}$.

Gugatan perdata tidak hanya gugatan wanprestasi saja tetapi juga didominasi oleh gugatan perbuatan melawan hukum. Wanprestasi berbeda dengan perbuatan melawan hukum. Perbuatan melawan hukum adalah suatu bentuk perikatan yang lahir dari Undang-Undang sebagai akibat dari perbuatan manusia yang melanggar hukum, yang diatur dalam KUHPerdata ${ }^{15}$. Perbedaan antara gugatan wanprestasi dengan perbuatan melawan hukum yaitu gugatan wanprestasi untuk menempatkan penggugat pada posisi dimana ganti rugi yang diberikan adalah kehilangan keuntungan yang diharapkan, sedangkan gugatan atas dasar perbuatan melawan hukum menempatkan penggugat pada posisi sebelum terjadi perbuatan melawan hukum tersebut sehingga ganti rugi yang diberikan adalah kerugian yang nyata. Tetapi, saat ini terjadi pergeseran teori yang sebelumnya adalah teori klasik yang membedakan terhadap dua gugatan tersebut menjadi teori modern yang tidak lagi membedakan secara tajam dari dua gugatan wanprestasi dan perbuatan melawan hukum. ${ }^{16}$

\footnotetext{
12 Darwan Prinst, Strategi Menyusun dan Menangani Gugatan Perdata, Bandung: PT. Citra Aditya Bhakti, 1992, hlm. 2

${ }^{13}$ Sudikno Mertokusumo, Hukum Acara Perdata, Yogyakarta: Liberty, 2002,, hlm. 38

14 Mahkamah Agung RI, Pedoman PelaksanaanTtugas dan Administrasi Pengadilan Jilid II, Jakarta, 1994, hlm. 125.

${ }^{15}$ Gunawan Widjaja dan Kartini Muljadi, Seri Hukum Perikatan yang Lahir Dari Undang-Undang, Jakarta: Raja Grafindo, 2003, hlm. 81.

${ }^{16}$ Rosa Agustina, Suharnoko, et. al , Hukum Kontrak (Law of Obligation), Bali: Pustaka Larasan, 2012, hlm. 12.
} 
Pengertian penggabungan gugatan atau kumulasi gugatan (samenvoeging van vorderings) yaitu penggabungan dari lebih satu tuntutan hukum ke dalam satu gugatan ${ }^{17}$. Ada 2 (dua) manfaat dan tujuan penggabungan gugatan, yaitu ${ }^{18}$ :

1. Mewujudkan peradilan sederhana

Melalui sistem penggabungan beberapa gugatan dalam satu gugatan, dapat dilaksanakan penyelesaian beberapa perkara melalui proses tunggal, dipertimbangkan serta diputuskan dalam satu putusan. Sebaliknya, jika masing-masing digugat secara terpisah dan berdiri sendiri, terpaksa ditempuh proses penyelesaian terhadap masing-masing perkara sehingga azas peradilan: "sederhana, cepat dan biaya ringan" tidak ditegakkan.

2. Menghindari putusan yang saling bertentangan

Manfaat yang lain, melalui sistem penggabungan dapat dihindari munculnya putusan yang saling bertentangan dalam kasus yang sama. Oleh karena itu, apabila terdapat koneksitas antara beberapa gugatan, cara yang efektif untuk menghindari terjadinya putusan yang saling bertentangan, dengan jalan menempuh sistem kumulasi atau penggabungan gugatan. Subekti berpendapat, untuk menghindari terjadinya putusan yang saling bertentangan mengenai kasus yang memiliki koneksitas, misalnya apabila pada pengadilan negeri tertentu terdapat dua atau beberapa perkara yang saling berhubungan, serta para pihak yang terlibat sama, lebih tepat perkara itu digabung menjadi satu, sehingga diperiksa oleh satu majelis saja.

Hukum positif tidak mengatur penggabungan gugatan, baik HIR, maupun Rbg, begitu pula dalam Rv tidak mengatur tentang penggabungan gugatan secara tegas dan tidak pula melarang. Pasal $103 \mathrm{Rv}$ melarang pegabungan gugatan atau kumulasi gugatan (samenvoeging van vordering) hanya terbatas pada menggabungkan antara tuntutan hak menguasai (bezit) dengan tuntutan hak milik. Dengan demikian secara a contrario (in the opposite sense), Rv membolehkan penggabungan gugatan ${ }^{19}$. Meskipun HIR dan Rbg maupun Rv tidak mengaturnya, peradilan sudah lama menerapkannya. Soepomo menunjukan salah satu putusan raad justisie Jakarta pada tanggal 20 juni 1939 yang memperbolehkan penggabungan gugatan, asal antara gugatan-gugatan itu terdapat hubungan erat (innerlijke samenhang) ${ }^{20}$.

Menganalisa perkara perdata mengenai kumulasi gugatan antara perkara wanprestasi dan perbuatan melawan hukum yang ditolak oleh hakim, secara teori

\footnotetext{
${ }^{17}$ Lilik Mulyadi, Hukum Acara Perdata Menurut Teori dan Praktek Peradilan Indonesia, Jakarta: Dajmbatan, Jakarta, hlm. 57.

18 http://www.hukumacaraperdata.com/gugatan/penggabungan-gugatan/, diakses pada tanggal 10 Desember 2018 pukul 12.22 WIB.

${ }^{19}$ M. Yahya Harahap, Op.cit, hal. 102.

${ }^{20}$ Soepomo, Hukum Acara Perdata Pengadilan Negeri, Jakarta: Pradnya Paramita, 1993 , hlm. 20.
} 
hukum acara perdata adalah telah benar. Hal ini berdasarkan alasan sebagai berikut:

1. Sumber hukum wanprestasi menurut Pasal 1243 KUHPerdata adalah timbul dari persetujuan (agreement) sedangkan sumber hukum dari perbuatan melawan hukum menurut Pasal 1365 KUHPerdata adalah timbul akibat perbuatan orang yang merugikan pihak yang lain.

2. Timbulnya hak menuntut dalam wanprestasi adalah hak menuntut ganti rugi berdasarkan Pasal 1243 KUHPerdata yang pada prinsipnya membutuhkan pernyataan lalai (somasi). Hak menuntut ganti rugi karena perbuatan melawan hukum tidak perlu melakukan somasi. Kapan saja terjadi perbuatan melawan hukum, pihak yang merasa telah dirugikan dapat langsung menuntut ganti rugi.

3. KUHPerdata telah mengatur tentang jangka waktu tentang perhitungan ganti rugi yang dapat dituntut serta jenis dan jumlah ganti rugi yang dapat dituntut dalam wanprestasi, sedangkan dalam perbuatan melawan hukum KUHPerdata tidak mengatur bagaimana bentuk dan rincian ganti rugi. Oleh karena itu, tuntutan perbuatan melawan hukum dapat digugat ganti rugi nyata dan kerugian immateriil.

Putusan pengadilan yang menolak gugatan yang mengandung kumulasi gugatan antara wanprestasi dan perbuatan melawan hukum dapat menimbulkan kontroversi karena pada intinya dalam hukum acara perdata, gugatan perbuatan melawan hukum dan wanprestasi harus dipisah atau tidak dapat digabung. Hal ini didasarkan pada ketentuan yang pertama bahwa terdapat perbedaaan dasar hukum tuntutan perbuatan melawan hukum dan wanprestasi. Dasar hukum perbuatan melawan hukum adalah Pasal 1365 KUHPerdata sedangkan dasar wanprestasi adalah Pasal 1243 KUHPerdata. Alasan yang kedua adalah timbulnya hak menuntut dalam gugatan perbuatan melawan hukum adalah ganti rugi yang tidak perlu dilakukan somasi, sedangkan hak menuntut dalam wanprestasi adalah ganti rugi yang dapat dilakukan somasi terlebih dahulu dengan pernyataan lalai. Hal yang ketiga adalah dalam hal pengaturan ganti rugi yang diatur dalam KUHPerdata telah jelas menyebutkan secara terperinci tentang jangka waktu perhitungannya, sedangkan dalam perbuatan melawan hukum tidak diatur.

Kumulasi terdiri dari dua macam, yaitu ${ }^{21}$ :

1. Kumulasi subyektif ialah penggabungan gugatan yang di dalamnya terdiri dari beberapa orang penggugat atau beberapa orang tergugat. Undangundang tidak melarang penggugat mengajukan gugatan terhadap beberapa orang tergugat, terhadap kumulasi subyektif ini tergugat dapat mengajukan keberatannya, yaitu tidak menghendaki kumulasi subyektif ${ }^{22}$. Dalam pasal 127 HIR dan pasal 151 R.Bg, serta beberapa pasal dalam Rv. dan BW

${ }^{21}$ Mukti Arto, Praktek Perkara Perdata Pada Pengadilan Agama, Yogyakarta: Pustaka Pelajar, 2005, Cet. ke-6, hlm. 44.

${ }^{22}$ Sudikno Mertokusumo, Op.Cit, hlm. 57. 
terdapat aturan yang membolehkan adanya kumulasi subjektif, di mana penggugat dapat mengajukan gugatan terhadap beberapa tergugat. Atas gugatan kumulasi subjektif ini tergugat dapat mengajukan keberatan agar diajukan secara sendiri-sendiri atau sebaliknya justru tergugat menghendaki agar pihak lain diikutsertakan dalam gugatan yang bersangkutan karena adanya koneksitas. Keinginan tergugat untuk mengikut sertakan pihak lain ini dituangkan dalam eksepsi "masih adanya pihak lain yang harus ditarik sebagai pihak yang berkepentingan". Tangkisan semacam ini disebut "exceptio plurium litis consurtium.",23

2. Kumulasi obyektif ialah jika penggugat mengajukan beberapa gugatan kepada seorang tergugat, namun agar penggabungan sah dan memenuhi syarat, maka harus terdapat hubugan erat ${ }^{24}$. Sebagai contoh gugatan yang tidak mensyaratkan adanya koneksitas misalnya, A dan B menggugat $\mathrm{C}$ dan $\mathrm{D}$ tentang warisan. Bersamaan itu pula diajukan gugat utang piutang oleh A dan B kepada C dan D. Dalam perkara ini tidak ada koneksitas antara perkara warisan dengan perkara utang piutang. Hal terpenting dalam perkara tersebut adalah para penggugat dan para tergugat orangnya sama dengan tidak disyaratkan adanya hubungan hukum antara gugatan-gugatan yang digabung. Terhadap kasus ini apabila diajukan kepada hakim yang mensyaratkan adanya koneksitas, maka gugatan utang piutang akan dinyatakan tidak dapat diterima karena tidak ada hubungan erat antara warisan dengan utang piutang. Adapun contoh kasus yang mensyaratkan adanya koneksitas misalnya gugatan perkara perceraian dengan gugatan nafkah, gugatan pembatalan suatu perjanjian dengan gugatan ganti kerugian, gugatan perbuatan melawan hukum dengan ganti kerugian dan lain-lain. Di lingkungan peradilan agama dikenal adanya kumulasi gugat antara perceraian dengan penguasaan anak, nafkah anak, nafkah isteri dan harta bersama.

Sudikno Mertokusumo ${ }^{25}$ dan Hensyah Syahlani ${ }^{26}$ menyatakan, untuk mengajukan komulasi objektif pada umumnya tidak disyaratkan tuntutan-tuntutan itu harus ada hubungan yang erat atau koneksitas satu sama lain, namun dalam praktek biasanya antara tuntutan-tuntutan yang digabung itu ada koneksitas. Pendapat yang mensyaratkan adanya koneksitas atau menurut istilah Seopomo hubungan batin (innerlijke samenhaang) antara lain Yahya Harahap ${ }^{27}$ dan Abdul Manan $^{28}$. Keharusan adanya koneksitas ini diikuti oleh Mahkamah Agung

\footnotetext{
${ }^{23}$ Ibid. hlm. 42

${ }^{24}$ M. Yahya Harahap, Op.Cit., hlm. 107.

${ }^{25}$ Sudikno Mertokusumo, Op.Cit, hlm. 42.

${ }^{26}$ Hensyah Syahlani, Pembuktian Dalam Beracara Perdata dan Teknis Penyusunan Putusan Pengadilan Tingkat Pertama, Yogyakarta: Grafgab Lestari, 2007, hlm. 73

27 Yahya Harahap, Op. Cit, hlm. 105.

28 Abdul Manan,Penerapan Hukum Acara Perdata di Lingkungan Peradilan Agama, Jakarta: Yayasan Al-Hikmah, 2000, hlm. 23.
} 
sebagaimana tertuang dalam Pedoman Pelaksanaan Tugas dan Administrasi Pengadilan Buku II dan beberapa putusan Mahkamah Agung antara lain: putusan Nomor 1518 K/Pdt/1983, putusan Nomor 1715 K/Pdt/1983 dan putusan Nomor 2990 K/Pdt/1990. Syarat adanya koneksitas juga pernah diputus oleh Raad van Justitie Jakarta tanggal 20 Juni 1939. Meskipun ada perbedaan pendapat tentang syarat koneksitas, akan tetapi terhadap dua hal di bawah ini mereka sepakat mengecualikan untuk memperbolehkan melakukan komulasi gugatan dalam hal:

1. Gugatan yang Digabungkan Tunduk kepada Acara yang Berbeda. Apabila gugatan-gugatan itu tunduk kepada hukum acara yang berbeda, maka gugatan tersebut tidak dapat digabungkan, misalnya dalam perkara pembatalan merk tidak bisa digabung dengan perkara perbuatan melawan hukum karena perkara pembatalan merk tunduk kepada hukum acara yang diatur dalam undang-undang merk yang tidak mengenal upaya banding, sementara perkara perbuatan melawan hukum tunduk kepada hukum acara biasa yang mengenal upaya banding. Dengan adanya kedudukannya pada hukum acara yang berbeda, maka antara keduanya tidak boleh dilakukan komulasi.

2. Gugatan yang Digabungkan Tunduk kepada Kompetensi Absolut yang Berbeda. Gugatan-gugatan yang dikumulasikan harus merupakan kewenangan absolut satu badan peradilan sehingga tidak boleh digabungkan antara beberapa gugatan yang menjadi kewenangan absolut badan peradilan yang berbeda. Perkara sengketa kewarisan bagi orangorang yang beragama Islam yang menjadi kewenangan peradilan agama tidak dapat digabungkan dengan perkara perbuatan melawan hukum yang menjadi kewenangan peradilan umum. Harus menjadi perhatian bagi hakim sering adanya maksud dari penggugat yang memanfaatkan komulasi gugat terhadap perkara yang tunduk kepada kompetensi absolut yang berbeda. Misalnya, seseorang yang telah kalah berperkara dalam kewarisan di Pengadilan Agama baik putusannya telah mempunyai kekuatan hukum tetap atau sedang dalam upaya hukum banding atau kasasi, ia mengajukan gugatan ke Pengadilan Negeri di bawah titel gugatan perbuatan melawan hukum yang dikumulasikan dengan gugat kewarisan. Maksud diajukannya gugatan tersebut tidak lain untuk mengelak dari kekalahannya atau untuk mengulur-ulur waktu agar eksekusi tidak dapat segera dijalankan terutama jika gugatan itu disertai dengan penyitaan. Penggugat berharap hakim Pengadilan Negeri akan menjatuhkan putusan yang memenangkan gugatannya, jikalau pun ternyata harus juga kalah, paling tidak dapat menunda eksekusi dengan alasan perkaranya masih dalam proses pemeriksaan apalagi jika objek sengketa diletakkan sita oleh Pengadilan Negeri sedang dalam perkara di peradilan agama tidak diletakkan sita. Menghadapi kasus demikian, hakim harus cermat dalam menyikapinya 
dengan tetap berpegang teguh kepada aturan-aturan yang tidak terpengaruh dengan maksud penggugat yang tidak baik. ${ }^{29}$

Kumulasi gugatan wanprestasi dan perbuatan melawan hukum melanggar tata tertib beracara karena keduanya harus diselesaikan tersendiri. Posita gugatan yang berdasarkan pada perjanjian, akan tetapi dalam petitum menuntut mengenai perbuatan melawan hukum dinilai mengandung kontradiksi, dan gugatan dinyatakan obscuur libel (tidak jelas).

Mahkamah Agung juga pernah mengeluarkan Yurisprudensi mengenai masalah kumulasi gugatan tersebut yaitu dalam Putusan MA No. 1875 K/Pdt/1984 tanggal 24 April 1986. Dalam putusan Mahkamah Agung tersebut, disebutkan bahwa: "Penggabungan gugatan perbuatan melawan hukum dengan perbuatan ingkar janji tidak dapat dibenarkan dalam tertib beracara dan harus diselesaikan secara tersendiri pula".

Yurisprudensi yang paling baru adalah Putusan Pengadilan Negeri Jakarta Pusat, tanggal 23 Agustus 2010, yang menolak gugatan perusahaan Amerika, North Atlantic Inc karena menggabungkan Wanprestasi dan perbuatan melawan hukum. Pengadilan Negeri Jakarta Pusat tidak menerima gugatan North Atlantic Inc dengan pertimbangan hukumnya Majelis menyatakan bahwa; "penggabungan antara gugatan wanprestasi dan perbuatan melawan hukum melanggar tertib hukum acara. Dengan Merujuk kepada beberapa yurisprudensi Mahkamah Agung tersebut, akhirnya gugatan North Atlantic Inc dinyatakan tidak dapat diterima oleh karena Gugatan Penggugat mengandung kumulasi gugatan wanprestasi dan perbuatan melawan hukum. Gugatan perbuatan melawan hukum dan wanprestasi memiliki hal yang berbeda secara prinsip karena gugatan wanprestasi harus didasarkan pada prestasi yang tidak dilakukan dalam perjanjian, sedangkan gugatan perbuatan melawan hukum didasarkan pada perbuatan yang tidak timbul dari perjanjian, oleh sebab itu keduanya harus diselesaikan masing- masing secara terpisah. Atas dasar Pertimbangan tersebut, maka Judex Juris dapat menyatakan bahwa gugatan yang mencampuradukkan gugatan wanprestasi dan perbuatan melawan hukum tersebut dinyatakan gugatan tidak dapat diterima niet Ontvankelijk Verklaard atau NO .

\section{Pertimbangan Hukum Dari Hakim Yang Menolak Kumulasi Gugatan Wanprestasi Dan Perbuatan Melawan Hukum Ditinjau Dari Hukum Acara Perdata Di Indonesia}

Putusan Pengadilan Negeri Kediri Nomor : 70 / Pdt.G / 2011/ PN.Kdr, dalam pertimbangannya hakim menyatakan bahwa:

1. Menimbang, bahwa mengenai eksepsi berdasarkan Cacatnya Kumulasi Subjektif dalam Gugatan, menurut Tergugat III dalam gugatannya

\footnotetext{
${ }^{29}$ http://eprints.walisongo.ac.id/3047/3/2105007_Bab\%202.pdf, diakses pada tanggal 30 Oktober 2018, pukul 15.44 WIB
} 
Penggugat mendalilkan adanya perbuatan wanprestasi yang dilakukan oleh Tergugat I dan II tapi Penggugat kemudian mengubah dasar gugatan kepada Tergugat III berdasarkan PMH, hal ini menimbulkan ekses bahwa antara Tergugat III jelas tidak memiliki hubungan hukum dengan Penggugat berdasarkan perbuatan wanprestasi. formulasi gugatan terutama pada kumulasi subjektif yang tidak jelas dengan mencampuradukkan PMH dengan Wanprestasi pada Tergugat I, II dan III secara sekaligus menjadikan gugatan aquo membingungkan serta menimbulkan konsekwensi pembuktian yang tidak sederhana atau rumit, sehingga dengan demikian gugatan mengandung cacat secara hukum, oleh karenanya gugatan haruslah dinyatakan tidak dapat diterima ;

2. Menimbang, bahwa mengenai eksepsi berdasarkan Exceptio Plurium Litis Consortium, menurut Tergugat III posisi Tergugat III dalam proses pembuatan perjanjian dengan nasabah (debitur) terkait dengan obyek berupa mobil (barang bergerak) tidaklah berdiri sendiri melainkan ada pihak lain didalamnya. Tergugat III hanyalah perantara dalam membantu para calon debitur (Tergugat I) dalam melakukan transaksi dengan produsen/ distributor mobil dengan tata cara dan persyaratan yang akan ditentukan kemudian oleh Tergugat III dalam Perjanjian Pembiayaan, dimana dalam hubungan ini Tergugat III menyebut UD Central Jaya Mobil yang beralamat di Jl. Kapten Tendean 149 B, Kediri sebagai perusahaan dealer mobil sebagai pihak lain yang terkaitdengan proses pembuatan perjanjian antara Tergugat I \& II dengan Tergugat III. Berdasarkan hal ini seharusnya Penggugat menarik pula UD Central Jaya Mobil yang beralamat di Jl. Kapten Tendean 149 B, Kediri sebagai pihak dalam gugatannya, namun hal ini tidak dilakukan sehingga gugatan Penggugat tersebut kekurangan pihak dalam gugatan (cacat plurium litis consortium). Oleh karenanya gugatan yang demikian harus dinyatakan tidak dapat diterima.

3. Menimbang, bahwa mengenai eksepsi tentang Exceptio Obscuur Libel, menurut Tergugat III penggabungan PMH dengan wanprestasi dalam satu Gugatan, melanggar tata tertib beracara atas alasan keduanya harus diselesaikan tersendiri. Penggabungan posita wanprestasi dan $\mathrm{PMH}$ dalam gugatan dengan no. register: 70/Pdt.G/2010/PN.Kdr mengandung cacat obscuur libel, oleh karenanya gugatan tersebut harus dinyatakan tidak dapat diterima;

4. Menimbang, bahwa setelah Majelis Hakim mencermati, eksepsi dari Tergugat III Konpensi terhadap gugatan Penggugat Konvensi secara umum eksepsi Tergugat III Konvensi, angka 1 Eksepsi berdasarkan Cacatnya Kumulasi Subjektif dalam Gugatan dan 3 Exceptio Obscuur Libel. terkait dengan penggabungan gugatan atau disebut juga kumulasi gugatan (samenvoeging van vordering) yaitu penggabungan lebih dari satu tuntutan hukum kedalam gugatan. Pada prinsipnya setiap gugatan harus berdiri 
sendiri. Masing-masing gugatan diajukan dalam surat gugatan yang terpisah secara tersendiri, dan diperiksa dan diputusan dalam proses pemeriksaan dan putusan yang terpisah dan berdiri sendiri. Namun untuk memudahkan proses dan menghindari putusan yang bertentangan penggabungan dapat dibenarkan sepanjang mempunyai hubungan yang erat ;

5. Menimbang, bahwa setelah Majelis Hakim mencermati gugatan Penggugat benar dalam posita angka 1, 5, 7, 8 dan 9 dihubungkan dengan petitum angka 2 gugatan Para Penggugat mendasarkan pada gugatan wanprestasi, sedang pada posita angka 2,3,4,6, dan 10 dihubungkan dengan petitum angka 4 gugatan para penggugat mendasarkan gugatan Perbuatan Melawan hukum ;

6. Menimbang, bahwa dalam praktik dikenal dua bentuk Penggabungan yaitu Kumulasi Subyektif dan Kumulasi objektif. Pada bentuk kumulasi subyektif dalam suatu surat gugatan terdapat beberapa orang Penggugat dan beberapa orang Tergugat. Dapat terjadi variabel sebagai berikut :

a. Penggugat terdiri dari beberapa orang berhadapan dengan seorang Tergugat saja;

b. Pengggugat satu orang sedang Tergugat terdiri dari beberapa orang ;

c. Dapat juga terjadi bentuk kumulasi subyektif yang meliputi pihak penggugat dan tergugat, pada kumulasi subyektif seperti ini penggugat terdiri dari beberapa orang berhadapan dengan beberapa orang Tergugat;

d. Dalam kumulasi subyektif agar tidak bertentangan dengan hukum sesuai dengan putusan Mahkamah Agung RI No. 2177 K/Pdt/ 1983 dan No. 1742 K/Pdt/1983 yang menegaskan diantara orang tersebut harus ada hubungan hukum. Penegasan yang sama terdapat pula dalam putusan Mahkamah Agung RI No. 524 K/Sip/1974 menegaskan gugatan yang diajukan kepada lebih dari seorang tergugat, dan diantara mereka tidak ada hubungan hukum , tidak dapat dilakukan dalam satu gugatan , tetapi masing-masing harus digugat secara tersendiri;

7. Menimbang, bahwa pengertian Kumulasi objektif yang digabung adalah gugatan Penggugat menggabung beberapa gugatan dalam satu surat gugatan. Jadi yang menjadi faktor kumulasi adalah gugatan, yaitu beberapa gugatan digabung dalam satu gugatan. Namun agar penggabungan itu sah dan memenuhi syarat, diantara gugatan itu harus terdapat hubungan erat. Penggabungan gugatan yang mencampur aduk antara kumulasi subyektif dan obektif, karena digabung peristiwa dan kepentingan hukum yang saling berlainan dan berdiri sendiri, sehingga tidak mungkin dilakukan proses penyelesaian kasus bertentangan dengan hukum sebagaimana dalam putusan Mahkamah Agung RI No. 1975 K/Pdt/1984 dan lebih ditegaskan lagi dalam putusan Mahkamah Agung RI No. 575 /Pdt/ 1983 yang menyatakan boleh melakukan penggabungan (samenvoeging) baik dalam 
bentuk subyektif dan objektif, asal terdapat hubungan erat (innerlijke samenhangen);

8. Menimbang, bahwa setelah Majelis Hakim mencermati gugatan para penggugat Konpensi sebagaimana telah diuraikan diatas, ternyata substansinya adalah ada gugatan wanprestasi yang ditujukan kepada Tergugat I dan II dan gugatan perbuatan melawan hukum yang ditujukan kepada Tergugat III, secara eksplisit disebut dalam perihal pokok surat gugatan Para Penggugat yaitu "Gugatan Wanprestasi dan adanya perbuatan Melawan hukum”, begitu juga dalam replik Penggugat angka 4 disebutkan pula bahwa "penggabungan perbuatan melawan hukum dengan gugatan wanprestasi menurut Penggugat dianggap tidak melanggar tertib beracara, karena Tergugat I dan Tergugat II serta Tergugat III adalah satu kesatuan sebab Tergugat I dan Tergugat II melakukan wanprestasi sedangkan Tergugat III melakukan perbuatan melawan hukum";

9. Menimbang, bahwa terhadap gugatan Para Penggugat Konpensi tersebut, Majelis Hakim berpendapat bahwa sesuai dengan putusan Mahkamah Agung sebagaimana terurai diatas dalam penggabungan gugatan disyaratkan keduanya terdapat hubungan erat (innerlijke samenhangen), dalam perkara ini menurut hemat Majelis Hakim antara gugatan wanprestasi yang ditujukan kepada Tergugat I dan Tergugat II dengan gugatan Perbuatan Melawan Hukum yang ditujukan kepada Tergugat III meskipun membunyai hubungan kausal, namun penggabungan yang demikian tidak tepat justru mengaburkan gugatan Para Penggugat. Selain itu Wanprestasi dan Perbuatan Melawan Hukum dalam hukum Perdata diatur secara sendiri-sendiri, sebagaimana dikatakan oleh Mr. Wirjono Prodjodikoro dalam bukunya Asas-asas Hukum Perjanjian, Penerbit Sumur Bandung hal 8 disebutkan "istilah verbintenissen dari Burgelijk Wetboek dapat diterjemahkan perikatan- perikatan . Dalam sitim B.W perikatanperikatan ini dibagi menjadi dua golongan (pasal 1312 B.W) yaitu :

a. Perikatan - perikatan yang bersumber pada persetujuan (overeenkomst).

b. Perikatan-perikatan yang bersumber pada undang - undang ( wet ).

Mengacu pada pendapat tersebut jelas bahwa wanperestasi didasarkan pada pelanggaran atas persetujuan atau perjanjian sedangkan perbuatan melawan hukum didasarkan pada pelanggaran undang-undang (wet). Berdasarkan uraian diatas Majelis Hakim tidak sependapat dengan Kuasa Hukum Para Penggugat yang menganggap penggabungan gugatan wanprestasi dengan gugatan perbuatan melawan hukum tidak melanggar tertib beracara. Secara tegas Mahkamah Agung telah menggariskan dalam penggabungan gugatan atau kumulasi gugatan subyektif dan objektif sesuai dengan putusan Mahkamah Agung RI No. 1652 K/Sip/1985 tidak dibenarkan penggabungan antara gugatan wanprestasi dan gugatan perbuatan 
melawan hukum karena tidak mempunyai hubungan erat (innerlijke samenhangen).

Menganalisa pertimbangan hakim di atas, penulis memiliki pertimbangan yang sama dengan pertimbangan hakim tersebut dengan alasan bahwa Gugatan wanprestasi dan gugatan perbuatan melawan hukum didasarkan pada ketentuan yang berbeda. Gugatan wanprestasi didasarkan pada adanya cidera janji dalam perjanjian sehingga salah satu pihak harus bertanggung jawab. Mengenai hal ini Pasal 1243 KUHPerdata yang menjadi dasar hukum wanprestasi, sedangkan untuk gugatan perbuatan melawan hukum didasarkan pada Pasal 1365 KUHPerdata. Apabila penggugat mengajukan gugatan perdata dengan dasar wanprestasi dan perbuatan melawan hukum, hal ini akan membingungkan hakim karena gugatan didasarkan pada dasar hukum yang berbeda sehingga gugatan menjadi tidak jelas (obscuur libel). Putusan Mahkamah Agung No. 1875 K/Pdt/1984 tertanggal 24 April 1986 juga menegaskan mengenai tidak dikabulkannya gugatan yang mengandung kumulasi gugatan antara wanprestasi dan perbuatan melawan hukum. Selain itu, dalam Putusan MA No. 879 K/Pdt/1997 tanggal 29 Januari 2001 juga dijelaskan bahwa penggabungan wanprestasi dan perbuatan melawan hukum dalam satu gugatan melanggar tata tertib beracara karena keduanya harus diselesaikan tersendiri.

\section{PENUTUP}

Suatu gugatan tidak dapat dibuat kumulasi gugatan antara wanprestasi dan perbuatan melawan hukum ditinjau dalam hukum acara perdata di Indonesia karena gugatan perbuatan melawan hukum dan wanprestasi memiliki perbedaan secara prinsip. Gugatan wanprestasi harus didasarkan dari prestasi yang tidak dilakukan dalam perjanjian, sedangkan gugatan perbuatan melawan hukum didasarkan pada perbuatan yang tidak timbul dari perjanjian, oleh sebab itu keduanya harus diselesaikan masing- masing secara terpisah.

Pertimbangan hukum dari hakim yang menolak terhadap kumulasi gugatan wanprestasi dan perbuatan melawan hukum, ditinjau dari hukum acara perdata di Indonesia telah sesuai dengan yurisprudensi Mahkamah Agung Nomor 1875 K/Pdt/1984 tanggal 24 April 1986 yang menyebutkan bahwa Kumulasi gugatan perbuatan melawan hukum dengan perbuatan ingkar janji/wanprestasi tidak dapat dibenarkan dalam tertib beracara dan harus diselesaikan secara tersendiri pula.

\section{DAFTAR PUSTAKA}

\section{Buku}

Abdul Manan, Penerapan Hukum Acara Perdata di Lingkungan Peradilan Agama, Jakarta: Yayasan Al-Hikmah, 2000.

Darwan Prinst, Strategi Menyusun dan Menangani Gugatan Perdata, Bandung: Citra Aditya Bhakti, 1992.

Efa Laela Fakhriah, Bukti Elektronik Dalam Sistem Pembuktian Perdata, edisi ke

2, Jakarta: Alumni, 2011. 
Gunawan Widjaja dan Kartini Muljadi, Seri Hukum Perikatan yang Lahir Dari Undang-Undang, Jakarta: Raja Grafindo, 2003.

Hensyah Syahlani, Pembuktian Dalam Beracara Perdata dan Teknis Penyusunan Putusan Pengadilan Tingkat Pertama, Yogyakarta: Grafgab Lestari, 2007.

I.P.M. Ranuhandoko, Terminologi Hukum, Cet. Kedua, Jakarta: Sinar Grafika, 2000.

Lilik Mulyadi, Hukum Acara Perdata Menurut Teori dan Praktek Peradilan Indonesia, Jakarta: Djambatan, 2002.

Mahkamah Agung RI, Pedoman PelaksanaanTtugas dan Administrasi Pengadilan Jilid II, Jakarta, 1994.

Munir Fuady, Perbuatan Melawan Hukum, Bandung: Citra Aditya Bakti, 2017.

Mukti Arto, Praktek Perkara Perdata Pada Pengadilan Agama, Yogyakarta: Pustaka Pelajar, 2005.

Merriam Webster's Dictionary of Lae, Merriam Webster, Springfield Massachussetts .

Rosa Agustina, Suharnoko, Hans Nieuwenhuis, dan Jaap Hijma. Hukum Kontrak (Law of Obligation), Bali: Pustaka Larasan, 2012.

Soedikno Mertokusumo, Hukum Acara Perdata, Yogyakarta: Liberty, 2002.

Sunarto, Peran Hakim dalam Perkara Perdata, Jakarta: Prenadamedia Group, 2014.

Soepomo, Hukum Acara Perdata Pengadilan Negeri, Jakarta: Pradnya Paramita, 1993.

Wirjono Prodjodikoro, Perbuatan Melanggar Hukum, Cetakan I, Bandung: Mandar Maju, 2000.

Yahya Harahap, Hukum Acara Perdata Tentang Gugatan, Persidangan, Penyitaan, Pembuktian dan Putusan Pengadilan, Jakarta: Sinar Grafika, 2006.

\section{Peraturan Perundang-Undangan}

Kitab Undang-Undang Hukum Perdata

Het Herziene Indonesisch Reglement (HIR)

Rechtsreglement voor de Buitengewesten (RBg).

Undang-Undang Nomor 48 Tahun 2009 Tentang Kekuasaan

\section{Putusan-Putusan}

Putusan Kasasi Mahkamah Agung No. 339K/Sip/1969

Putusan Kasasi Mahkamah Agung No. 1001K/Sip/1972

Putusan Kasasi Mahkamah Agung No. 77K/Sip/1973

Putusan Kasasi Mahkamah Agung No. 575 K/Pdt/1983

Putusan Kasasi Mahkamah Agung No. 1875 K/Pdt/1984

Putusan Kasasi Mahkamah Agung No. 1875 K/Pdt/1984

Putusan Kasasi Mahkamah Agung No. 886 K/Pdt/2007

Putusan Kasasi Mahkamah Agung No. 571 PK/Pdt/2008 
Dialogia luridica: Jurnal Hukum Bisnis dan Investasi

Volume 10 Nomor 2, April 2019

Putusan Pengadilan Negeri Kediri Nomor : 70 /Pdt.G/2011/PN.Kdr

Putusan Peninjauan Kembali Mahkamah Agung No. 571 PK/Pdt/2008

\author{
Sumber Lainnya \\ https://m.hukumonline.com \\ pkbh.uad.ac.id \\ http://www.hukumonline.com/klinik/detail/lt4da27259c45b9/di-mana- \\ pengaturan-kerugian konsekuensial-dalam-hukum-indonesia. \\ http://www.hukumacaraperdata.com/gugatan/penggabungan-gugatan/ \\ http://eprints.walisongo.ac.id/3047/3/2105007_Bab\%202.pdf. \\ http://www.msplawfirm.co.id/hakim-boleh-ultra-petita.
}

